\title{
Feasibility of Group Risk Income Protection Insurance for Para Rubber in Thailand*
}

\author{
Krittiya DUANGMANEE ${ }^{1}$
}

Received: August 01, 2020 Revised: September 06, 2020 Accepted: September 10, 2020

\begin{abstract}
The study investigates a promising sustainable crop-insurance risk mitigation plan, namely, Group Risk Income Protection (GRIP) insurance, for the cultivation of Para rubber, a crop for which Southern Thailand constitutes over half of the national harvested area, but which recently experienced a shift in prices and yields, substantially affecting farmers. The research takes as its starting point historical data covering the 2001-2018 period for this crop's cultivation in three of Thailand's Andaman South Coast provinces - Trang, Krabi, and Phangnga. The results indicate that, from a relatively high base in 2001, Trang's yields dropped sharply before a more gradual decline (apparently still ongoing), whereas those for Krabi and Phangnga followed a smoother downward trajectory throughout the period. Meanwhile, prices everywhere rose steadily before falling from 2011 onwards - a decrease that shows no signs of abating. The yield/price relationship was negative for one province and slightly positive for the other provinces. Furthermore, all provinces' Para rubber income initially grew continually but fell after 2011, with this trend seemingly persisting to this day. The paper's findings suggest that, after early moves to entrench GRIP insurance, it looks set to become a feasible option for Para rubber, making policy agreement details an interesting subject for subsequent investigations.
\end{abstract}

Keywords: Andaman South Coast Provincial Group, Group Risk Income Protection Insurance, Para Rubber Cultivation, Thailand

JEL Classification Code: G22, Q14, C14

\section{Introduction}

One of the strategies set out in Thailand's 11 th National Economic and Social Development Plan 2012-2016 is the "Strategy to Strengthen Food and Energy Security and the Agricultural Sector" (Office of the National Economic and

\footnotetext{
*Acknowledgements:

The author would like to warmly thank the editor and anonymous reviewers for the opportunity to publish this paper here and for their very useful input. Furthermore, she wishes to express her sincere thanks to Professor Preecha Vijitthammaros for his kind guidance as well as for being unfailingly generous with his valuable time. Last but not least, she is very grateful for all the other support she received in conducting this research, which was funded by Prince of Songkla University - Trang Campus, Thailand.

${ }^{1}$ First Author and Corresponding Author. Lecturer, Faculty of Commerce and Management, Prince of Songkla University - Trang Campus, Thailand [Postal Address: Faculty of Commerce and Management, Prince of Songkla University - Trang Campus, Muang District, Trang, 92000, Thailand] Email: krittiyad@yahoo.com

(c) Copyright: The Author(s)

This is an Open Access article distributed under the terms of the Creative Commons Attribution Non-Commercial License (https://creativecommons.org/licenses/by-nc/4.0/) which permits unrestricted non-commercial use, distribution, and reproduction in any medium, provided the original work is properly cited.
}

Social Development Board (NESDB), 2012). This plan underlines the key role the agricultural sector has played in consolidating the production base and ensuring an adequate domestic food supply. It has also provided income for agricultural families, promoted value creation for goods and services, and led to the generation of renewable energy. One of the proposed solutions to empower the agricultural sector and enhance the job security, income, and quality of life of the workers operating in it is crop insurance. Among other items, the number of farmers using the crop-insurance system, which offers them a wide range of assistance, is a reflection of the plan's success.

Historically, Thailand's first experience of crop insurance was a policy providing indemnity-insurance cover against all natural risks for cotton, established in 1978 in Pak Chong District, forming part of Nakorn Ratchasrima Province (Jeerachaipaisarn, 2012; Manuamorn, 2009). This program was revived from 1982 to 1984, and then a number of years later, from 1990 until 1991, all-risks insurance was laid on for maize, sorghum, and soybean crops. Subsequently, weather-index insurance for maize and rice was launched. Finally, in the past 10 years or so, the coverage provided by 
weather-index insurance policies has been adjusted to bring this type of insurance into line with prevailing conditions.

Para rubber ranks among Thailand's leading agricultural exports. The Office of Agricultural Economics (OAE) (2018a) reveals that nearly $50 \%$ of the country's surface area is used for agriculture, including notably Para rubber, with Southern Thailand accounting for more than half of the nationwide total growing area for this crop. Recently, a shift seems to have taken place in terms of both price and yield in Thailand. This is a result of several factors, including economic conditions and the occurrence of natural disasters, with the substantial impact they have had on Thai farmers. Therefore, this research examines a promising sustainable plan for crop-insurance risk mitigation covering Para rubber cultivation, namely, Group Risk Income Protection (GRIP) insurance, which is a county-based revenue product in which payments and guarantees are determined with the aid of county yields instead of farm yields. For logistical reasons, three provinces were studied within Southern Thailand's Andaman South Coast Provincial Group, namely, Trang, Krabi, and Phangnga; this is because it turns out that these provinces have substantial cultivation areas for Para rubber, representing around $90 \%$ of the total for this region.

In conclusion, this paper sets out to investigate the yield and price characteristics of Para rubber and the relationship between them. Viewed in this light, it constitutes a first step towards entrenching the GRIP policy type as a permanent feature of the insurance landscape in Thailand. In this way, corresponding anticipated premium rates will be put in place, forming the subject matter for subsequent investigations by the author. This will be followed by the establishment of a knowledge-management plan so that farmers can access this kind of insurance and gain a genuine understanding of what it involves. This study and the research following on from it aim to make a significant contribution to the development of a framework for the optimization of the crop-insurance system in Thailand and the provision of sustainable assistance to those involved in and associated with Para rubber cultivation, thereby enabling the objectives of the National Economic and Social Development Plan to be met.

\section{Literature Review}

\subsection{General Information on Para Rubber Growing in Thailand and the Relevant Crop Insurance Policy}

According to the Office of Agricultural Economics (OAE) (2018a), Thailand has a total area of around 321,000,000 rai (approximately 51,360,000 ha on the basis of 1 rai being equivalent to $0.16 \mathrm{ha}$ ). Based on the same source, almost half of Thailand's total surface area is used for agricultural purposes. Meanwhile, the cultivation area for Para rubber is $22,626,277$ rai. Within this, Southern Thailand has a growing area of around $13,584,115$ rai, thus accounting for $60.04 \%$ of the nationwide total for this crop. This is by far the highest percentage share for Para rubber cultivation among the respective agricultural land areas in any of the Thai regions. Moreover, this perennial crop leads the agricultural export market.

In 2016, 2017, and 2018, Para rubber had export values of 200,098, 287,744, and 221,412 million baht, respectively (Office of Agricultural Economics (OAE), 2018b), corresponding to around $6,408,9,215$, and 7,091 million US dollars, respectively, based on an exchange rate of 31.23 baht to 1 US dollar.

South-East Asia is the world's premier region for natural-rubber production and exports (Oktora \& Firdani, 2019). Thailand is a particular powerhouse in this regard, with Office of Agricultural Economics (OAE) (2018b) reporting that in 2017, it was the world's top rubber exporter (around 3.56 million metric tons), followed by Indonesia (around 3.31 million metric tons), Vietnam (approximately 1.36 million metric tons), and Malaysia (approximately 1.21 million metric tons).

Thailand produces various types of Para rubber for domestic use, for example, for the automotive industry and for glove and rubber-band manufacturing: Ribbed Smoked Sheet or Rubber Smoked Sheet (RSS), STR20 (Standard Thai Rubber Grade 20), and concentrated latex compound, among others (Office of Agricultural Economics (OAE), 2018b). Interestingly, latex harvesting involves several factors: the Food and Agriculture Organization of the United Nations (FAO) (1977) suggests (1) making a decent incision; (2) harvesting the latex effectively; and (3) harvesting the latex at an appropriate time. Commodity markets playing a crucial role in the trading of commodity futures are the Singapore Commodity Exchange (SICOM), especially for RSS3 (or Ribbed Smoked Sheet (RSS) Grade 3) and STR20 (or on the SICOM market, Technically Specified Rubber (TSR) Grade 20) rubber futures contracts, and the Tokyo Commodity Exchange (TOCOM), for RSS3 rubber futures contracts. In addition, the 'Thailand Daily Rubber Price' can be found in the form of a local market price and a 'bid price' at the Central Rubber Market in Hat Yai and on the FOB market (Bangkok). It turns out that RSS3 has the highest price (Office of Agricultural Economics (OAE), 2018b).

\subsection{Crop Insurance Policies}

There are a number of crop insurance policies - a type of risk management tool - that have been designed for crops in various countries. Smith (2003) reports that in the United States, federal crop insurance has been available since 1938 for some crops to protect against individual farm yield losses, 
in the form of multiple-peril policies. In addition, from the late 1980s onwards, as well as traditional multiple-peril contracts, new policies were devised on the basis of yield losses at county level. Furthermore, Smith (2001) claims that since the late 1980s, producers of a number of major crops have been able to use federal Group Risk Plan (GRP) contracts to insure against yield loss.

For farmers who encounter problems regarding income from production, Rafia et al. (2019) reveal that remedies, which can offer succor in countries such as Malaysia, include waqf cash support (a form of charitable endowment under Islamic law). One of their findings is that perceived barriers and awareness have a greater effect on farmers who are older and wealthy and have a high level of education, and that information can be communicated by the government through activities to make young and less educated farmers more aware of the potential risk and impact of climate change. Another solution likely to be appealing to such individuals and their households is provided by revenueinsurance policies offering indemnities for revenue losses as a result of low yields or prices, or a combination of both. Four major types of revenue-insurance policies are distributed in the United States (Smith, 2003).

Under GRIP insurance policies, low average revenue for the crop in an individual county triggers indemnity payments. This means that if total revenue (price $\times$ yield) in a given county is below a producer's trigger revenue, the producer will receive indemnification for revenue losses, according to Johnson and Hewlett (2006), who also reveal that several terms used in this policy type, e.g. Expected County Yield and Expected Price, can be multiplied together to produce the Expected County Revenue. Thus, understanding the characteristics of the expected yield and the anticipated price and the relationship between them is crucial in this kind of policy. Johnson and Hewlett (2006) indicate that the Expected County Yield is the yield mentioned in actuarial documents, which serves as a basis for a producer's coverage of a crop, while the Expected Price is set out in the crop provisions governing each specific crop covered by a GRIP insurance policy. Edwards (2011) offers an example of two choices for the expected price: an average CBOT futures price for a given month (e.g. February); and a Harvest Price Option (HPO), under which the harvest futures price is used to work out the trigger revenue if it exceeds the price for the month in question (so February in the example). One notable feature is that GRIP policies do not supply coverage for delayed or prevented planting since these losses relate to individual farming operations and are therefore not applicable to a group-risk income situation (Johnson \& Hewlett, 2006).

Scholars' ongoing efforts to chronicle interesting situations have led to a variety of crop-insurance techniques being investigated. For instance, Walters and Preston (2013) address revenue risk encountered by producers. They explore the interaction between forward contracts (which should be used if prices decrease) and crop insurance (which should be used if yields decrease) to reduce revenue risk, showing that an understanding of the underlying price-yield relationship is crucial. Barnaby (2010) mentions that as of the autumn of 2010, the Risk Management Agency (RMA) would bring Actual Production History, Income Protection, Revenue Assurance, and Crop Revenue Coverage together into a single Common Crop Insurance Policy (CCIP), which would offer three types of coverage: Yield Protection (YP), Revenue Protection (RP), and Revenue Protection with the Harvest Price Exclusion (RP-HPE).

\section{Methodology}

This research examines yield, price, and income for Para rubber cultivation in three selected provinces on Thailand's Andaman South Coast, namely Trang, Krabi, and Phangnga, and the relevant trends, drawing on historical data for Para rubber cultivation in the three chosen provinces from 2001 to 2018. The main focus of this study is provided by nonparametric statistics, in which functions' distributions are not specified in advance and there is a much wider range of fits to the data than in the parametric approach, i.e. spline regression. Hence, spline regression is one of the nonparametric procedures Keller (2009) called "distributionfree statistics". Spline regression is a particular example of polynomial regression - indeed, independent variables are known as 'spline variables'. The spline fits will capture the data and adjust the slopes at the defined knots with no jumps at the respective points. The presentation of the models to illustrate trends in each province is based on Faraway (2006).

\section{Results and Discussion}

\subsection{General Information on Para Rubber Growing in Each Province}

Trang Province has a population of 643,116 (National Statistical Office (NSO), 2018), with a harvested area cultivating 1,457,213 rai of Para rubber (Office of Agricultural Economics (OAE), 2018a). Thailand has conducted six agricultural censuses to date, in 1950, 1963, 1978, 1993, 2003, and 2013 (as the years here show, these have been held every 10 years in recent decades). Based on the most up-to-date agricultural census information on farmer numbers that was provided by the latest iteration, in 2013, Trang had 86,983 farmers (Department of Agricultural Extension (DOAE), 2013) (number of farmers being used instead of number of farms due to limited data) and a Gross Provincial Product (GPP) of 64,586 million baht (Office 
of the National Economic and Social Development Board (NESDB), 2018).

As Para rubber trees are commonly cropped by smallholder producers, the relevant farms are sometimes in remote areas. Therefore, in addition to trading their products at rubber-fund cooperatives or private rubber companies, an alternative solution they use for selling their rubber is to make sales at local stalls, kiosks, or markets. These can be observed along the roadside on a typical morning.

Krabi Province numbers a population of 473,738 (National Statistical Office (NSO), 2018) and has a harvested area of 559,034 rai cultivating Para rubber (Office of Agricultural Economics (OAE), 2018a). It has 43,444 farmers (Department of Agricultural Extension (DOAE), 2013) and a GPP of 86,684 million baht (Office of the National Economic and Social Development Board (NESDB), 2018).

The population of Phangnga Province is 268,240 (National Statistical Office (NSO), 2018). Its harvested area cultivating Para rubber is 622,647 rai (Office of Agricultural Economics (OAE), 2018a), and it has 31,329 farmers (Department of Agricultural Extension (DOAE), 2013) and a GPP of 78,493 million baht (Office of the National Economic and Social Development Board (NESDB), 2018).

\subsection{Organizations and Points of Reference for Rice Growers across the Three Provinces}

\subsubsection{Rubber-Fund Cooperatives}

One type of organization playing a key role in Para rubber growing is the rubber-fund cooperative. Recently, the Rubber Authority of Thailand (RAOT) has established the Good Manufacturing Practice (GMP) initiative. The RAOT awards certification to any factory meeting the criteria. Furthermore, this initiative seems to help maintain the stability of Para rubber prices, potentially improving future exports.

There are five factories in Trang Province that meet the GMP standard for high-quality RSS production. One of these is Wang Kee Ree Rubber Fund Cooperative Ltd., which obtained GMP certification in 2016. Production at this factory follows the guidelines set by the RAOT, meaning that customers are guaranteed quality-assured rubber products.

\subsubsection{The Central Rubber Market in Hat Yai (Songkla Province)}

The Central Rubber Market in Hat Yai (Songkla Province) is one of the main hubs where producers are able to buy and sell rubber products in Southern Thailand. Among its primary functions is to act as a benchmark in providing a local reference price. As this market ensures that all purchases and sales are conducted fairly with regard to, for example, weights and prices, farmers need to continually make improvements to their products to meet the relevant requirements. Although at the Central Rubber Market, sellers charge higher prices than at local markets or stalls, resulting in increased revenue, smallscale producers seem to be deterred by additional costs, such as transport.

\subsection{Para Rubber Yields and Prices in Each Province}

This section addresses Para rubber yields and prices in each province. Due to limitations in the data collected from the RAOT in the individual provinces, this study draws on two sources in relation to yields, namely, the Office of Agricultural Economics (OAE) (2018a) for the rubber type (unsmoked rubber sheet), and the Rubber Authority of Thailand (RAOT) (2017) for local prices based on the Central Rubber Market in Hat Yai. Finally, the link between them will be established based on the straightforward assumption that the product to which these yields and prices pertain will generate income.

\subsubsection{Trang Province}

The Para rubber yield in Trang Province was fairly high at the start of the period under investigation, specifically standing at a level of just under $300 \mathrm{~kg} / \mathrm{rai}$ in 2001. Subsequently, the trend for this variable declined dramatically until 2010 and gradually dropped further from 2011 onwards, as can be seen in Figure 1 (the grey band shows a $95 \%$ confidence interval). As regards Para rubber prices in this province, these were just over $20 \mathrm{baht} / \mathrm{kg}$ in 2001 before rising constantly to reach around $130 \mathrm{baht} /$ $\mathrm{kg}$ in 2011, with prices trending downwards at a constant moderate rate after that. Income (indicated by 'Revenue' in the figure) is determined by calculating the product of yield and price. The trend for income generated by Para rubber cultivation in Trang steadily increased from 2001 (when this income stood at more than 6,000 baht/rai) until 2011 (when it came to around 30,000 baht/rai) before a downturn, which has continued in the subsequent years. This is in line with Oktora and Firdani (2019), who report that in South-East Asia there was a peak in natural rubber prices in 2011 and these then continued to decline, with this being linked to the global economic slowdown, especially in China, and to a drop in oil prices.

Finally, the study reveals a negative yield/price relationship for Trang Province, the specific value generated being -0.3964095 , meaning that increasing yields were accompanied by a decrease in prices. 


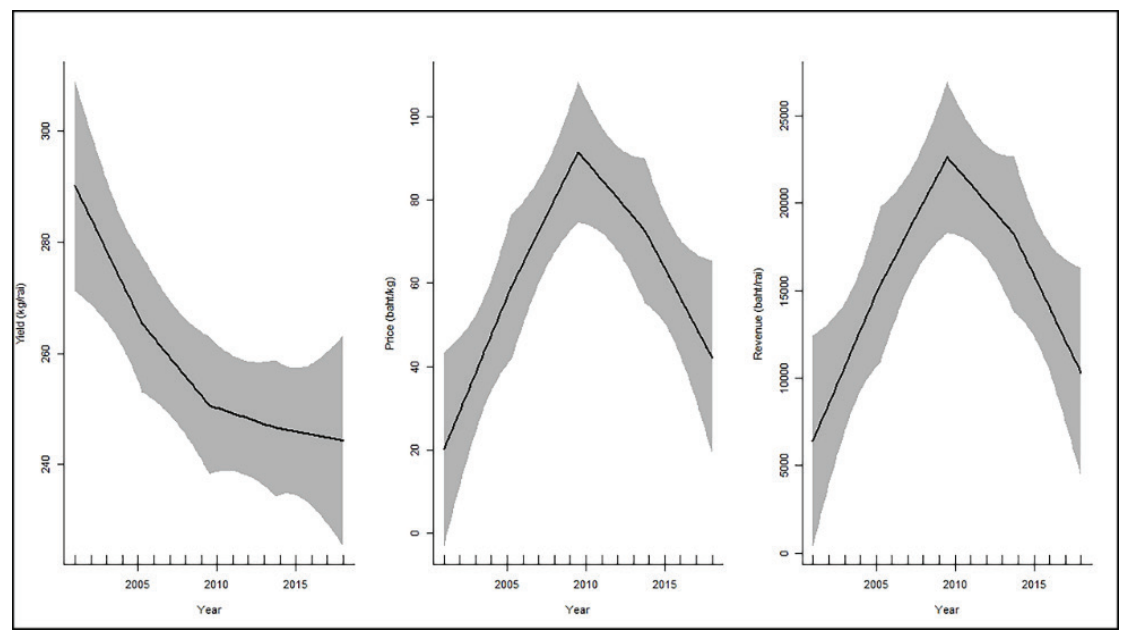

Figure 1: Para Rubber Yield, Price, and Revenue in Trang Province

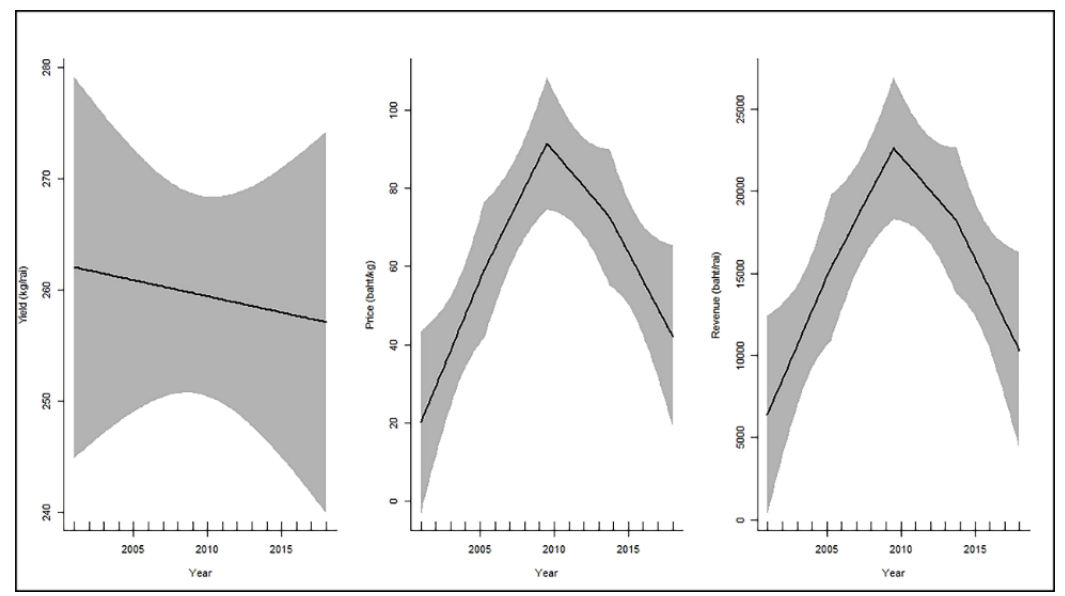

Figure 2: Para Rubber Yield, Price, and Revenue in Krabi Province

\subsubsection{Krabi Province}

The Para rubber yield in Krabi Province for the period being studied was lower on average than in Trang, coming to just over $263 \mathrm{~kg} / \mathrm{rai}$ in 2001, in other words, the start of the period under investigation. After that, there appears to have been a downward trend for yield, as can be seen in Figure 2. As for Para rubber prices in Krabi Province, this figure indicates the same price characteristics as Trang and also as Phangnga Province. This is because purchases and sales of rubber products in this part of Thailand are based on prices at the Central Rubber Market in Hat Yai. The graph for the income generated by Para rubber cultivation in Krabi Province is similar to the corresponding graph for Trang. This income in Krabi rose from more than 5,000 baht/ rai in 2001 to approximately 35,000 baht/rai in 2011, before declining in the subsequent years.
Last but not least, a positive relationship between yield and price was found for Krabi Province, namely, a value of 0.108328 , meaning that increasing yields resulted in a slight uptick in prices.

\subsubsection{Phangnga Province}

The Para rubber yield in Phangnga Province throughout the period studied followed a steady downward trajectory. However, the price decrease was less pronounced than in Krabi Province. The Para rubber price in Phangnga Province was the same as the two provinces discussed above. The graph for the income generated by Para rubber cultivation in Phangnga Province, too, is similar to Trang and Krabi. It increased from over 5,000 baht/rai in 2001 to around 35,000 baht/rai in 2011. It is noteworthy though that this was followed by a steeper decline than in the case of those provinces. 


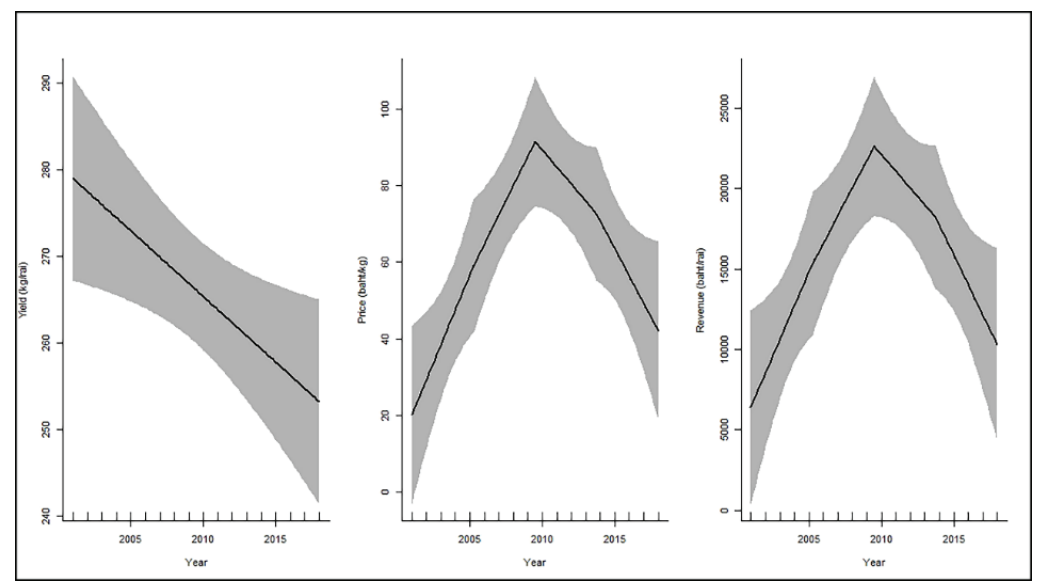

Figure 3: Para Rubber Yield, Price, and Revenue in Phangnga Province

Finally, a positive relationship was found between yield and price for Phangnga Province (0.005404), suggesting that a rise in yields is accompanied by only a very marginal increase in prices.

All in all, it can be clearly seen that income appears to follow a similar trajectory in each province.

\section{Conclusions}

Para rubber is one of Thailand's main exports. Given the recent changes in price and yield for this product as a result of various factors, this research has examined a promising option for sustainable crop-insurance risk mitigation in the case of Para rubber cultivation, namely, Group Risk Income Protection (GRIP) insurance. This research was conducted in three of the five provinces forming the Andaman South Coast Provincial Group, specifically, Trang, Krabi, and Phangnga. This initially involved investigating the yield and price characteristics of Para rubber and the relationship between them in these provinces.

The research revealed that the province with the largest population, Trang, also had the largest harvested area for Para rubber and the biggest number of farmers. In each of these respects it was followed by, first, Krabi and, second, Phangnga. However, Krabi led these three provinces in terms of Gross Provincial Product (GPP), being followed by Trang and then Phangnga.

Trang had a unique trend in terms of yield, in that in this province it declined sharply from a fairly high level in 2001 until 2010 before decreasing more gradually for the rest of the period being investigated - a trend that seems set to continue. In contrast, for this variable both of the other provinces, Krabi and Phangnga, trended downwards steadily throughout the period, and it is striking that this downward trajectory seemingly shows no sign of abating to this day.
Prices in the three provinces rose steadily in the early years of the period examined here, hitting around 130 baht/ $\mathrm{kg}$ in 2011, due to for instance the demand for Para rubber and a change in weather conditions in competing countries. However, they consistently decreased in the years after that, and it appears that this is a trend that has carried on beyond the time frame covered by this investigation.

For income, the study reveals similarities between the provinces. Producers enjoyed steady rises in the period's initial years, but after 2011, income began to fall - again, this seems set to continue.

Moreover, in one province (Trang) there was a negative relationship between yield and price, whereas in the other two provinces (Krabi and Phangnga) there was a marginally positive relationship between these variables. This could mean, in general, that an increase in yield would lead to a considerable increase/decrease in prices (as a result of supply and demand both domestically and internationally (given that rubber is a commodity that is traded globally)).

The investigation found that smallholders have a number of outlets to choose from when selling their products especially their latex and unsmoked rubber-sheet wares. Among these are local stalls, kiosks, and markets. One of the main benefits of these settings is the savings on transport vis-à-vis travelling further afield. The alternative is for these farmers to sell their goods at the Central Rubber Market in Hat Yai (Songkla Province) - while due to the greater distance that probably needs to be covered to trade there, it usually costs more to transport their products to this market than to a local market or stall for instance, but they can charge higher prices there (however, the price difference between the Central Rubber Market and local stalls and markets is generally no more than $2 \mathrm{baht} / \mathrm{kg}$ ).

Rubber-fund cooperatives, which are set up near concentrations of registered farmers, play a key role for 
farmers. This could lead to a certain level of bargaining power, in other words, buyers and sellers having specific relative strengths in influencing the terms of exchange in the context of a transaction (Kohls \& Uhl, 2002). As Trang has various outstanding rubber-fund cooperatives whose quality is guaranteed by GMP certification, this province could be used as a pilot for the GRIP insurance policy. In addition, cooperatives could act as an insurance entity with the introduction of, as a tool to complement GRIP, deposit insurance, as set out by Choi and Cho (2019) - an insurance system which, based on that paper, would lower the total risk level for insurers, as opposed to banks and security companies.

All in all, the results from this research should make a vital contribution to efforts, on the one hand, to optimize the crop-insurance system and, on the other, to provide sustainable support to those involved in Para rubber cultivation or associated with it in some form. Furthermore, the study suggests that GRIP insurance would be a feasible way of stabilizing the income from Para rubber production in the three provinces examined as it utilizes county yields (or province yields in the Thai context) instead of farm yields, avoiding the data limitation problems at farm level in Thailand. Although there is price volatility among Para rubber products, local prices (based on prevailing global market prices) at the Central Rubber Market can be referred to in terms of generating income. In the future, the SICOM and TOCOM markets could be used as a benchmark for guaranteed prices, along with other related and appropriate financial instruments. In this light, in subsequent activities the investigator will need to establish expected premium rates, a policy implementation process, and a knowledgemanagement plan for a GRIP insurance contract. Moreover, the study can be extended to other provinces and years of investigation. Ultimately, this information can be used by the relevant organizations (e.g. the Thai Department of Agricultural Extension (DOAE), agricultural market organizations, and the Rubber Authority of Thailand (RAOT)) to put in place sustainable plans to tackle the problems farmers in these provinces have faced in recent years, with the possibility of extending the relevant solutions nationwide. Success in this endeavor could pave the way for a similar system to be replicated by - or at least serve as a blueprint for - other countries in the region and further afield facing challenges of the same nature, thereby affording farmers and rural communities another means of improving their circumstances.

\section{References}

Barnaby, G. A., Jr (2010). Yield Protection Crop Insurance will have the same Yield Coverage as Revenue Protection, but $\mathrm{RP}$ is Expected to Be the Preferred Choice (Update). $\mathrm{Ag}$
Manager. Retrieved August 23, 2020, from https://docplayer. net/4699790-Yield-protection-crop-insurance-will-havethe-same-yield-coverage-as-revenue-protection-but-rp-isexpected-to-be-the-preferred-choice-updated-1.html.

Choi, J., \& Cho, D. (2019). Risk-Seeking Behavior of Financial Institutions due to Deposit Insurance: Evidence from Korea. Journal of Asian Finance, Economics and Business, 6(1), 8389. http://doi.org/10.13106/jafeb.2019.vol6.no1.83.

Department of Agricultural Extension (DOAE) (2013). Agricultural Census. Retrieved February 10, 2018, from http://www. agriinfo.doae.go.th/5year/census/order56.pdf (in Thai).

Edwards, W. (2011). Group Risk Plan (GRP) and Group Risk Income Protection (GRIP). Ag Decision Maker: Crops, File A1-58/FM-1850. Retrieved November 9, 2019, from https:// store.extension.iastate.edu/product/Group-Risk-Plan-GRPand-Group-Risk-Income-Protection-GRIP.

Faraway, J. J. (2006). Extending the Linear Model with R: Generalized Linear, Mixed Effects and Nonparametric Regression Models (1st ed.). Boca Raton, FL: Chapman \& Hall/CRC.

Food and Agriculture Organization of the United Nations (FAO) (1977). The rubber tree. FAO Economic and Social Development Series No. 3/25. Retrieved August 23, 2020, from http://www.fao.org/3/ad221e/AD221E00.htm.

Jeerachaipaisarn, T. (2012). Recent Developments of Crop Insurance in Thailand. Presentation by Thanad Jeerachaipaisarn for the General Insurance Association, January 26, 2012, Bangkok, Thailand. Retrieved September 16, 2019, from http://www. oecd.org/insurance/insurance/49657525.pdf.

Johnson, J. B., \& Hewlett, J. (2006). Group Risk Income Protection. Agricultural Marketing Policy Paper No. 13, July 2006. Bozeman, MT: Montana State University Cooperative Extension Service.

Keller, G. (2009). Managerial Statistics (8th ed.). France: SouthWestern France, Cengage Learning.

Kohls, R. L., \& Uhl, J. N. (2002). Marketing of Agricultural Products (9th ed.). Upper Saddle River, NJ: Prentice Hall.

Manuamorn, O. (2009). Rainfall Index-Based Insurance for Maize Farmers in Thailand: Review of Pilot Program 2006-2008. Experiential briefing note prepared by Ornsaran Pomme Manuamorn, Agriculture and Rural Development Department, the World Bank, January 2009. Retrieved August 23, 2020, from http://documents1. worldbank.org/curated/en/486101468312352024/ pdf/775860BRI0Thai0Box0342041B00PUBLIC0.pdf.

National Statistical Office (NSO). (2018). Population Size. Retrieved June 27, 2020, from http://statbbi.nso.go.th/ staticreport/page/sector/th/01.aspx (in Thai).

Office of Agricultural Economics (OAE). (2018a). Agricultural Statistics of Thailand 2018. Bangkok, Thailand: Ministry of Agriculture and Cooperatives.

Office of Agricultural Economics (OAE).. (2018b). The status of key agricultural products in 2018 and trends in these products 
in 2018. Bangkok, Thailand: Ministry of Agriculture and Cooperatives (in Thai).

Office of the National Economic and Social Development Board (NESDB). (2012). The Eleventh National Economic and Social Development Plan 2012-2016. Retrieved October 30, 2019, from https://www.nesdc.go.th/nesdb_en/ewt_dl_link. php?nid=3786.

Office of the National Economic and Social Development Board (NESDB). (2018). Gross Regional and Provincial Product. Chain Volume Measure 2018 Edition. Retrieved February 18, 2020, from https://www.nesdc.go.th/nesdb_en/ewt_dl_link. php?nid=4317\&filename=national_account.

Oktora, S. I., \& Firdani, A. M. (2019). Natural Rubber Economics between China and Southeast Asia: The Impact of China's Economic Slowdown. Journal of Asian Finance, Economics and Business, 6(2), 55-62. https://doi.org/10.13106/jafeb.2019. vol6.no2.55

Rafia, A., Muhibbullah, M., \& Morshed, N. (2019). Factors affecting the intention of the rice farmers to adopt the integrated cash waqf environmental protection model: an empirical study in Kedah Malaysia. Journal of Asian Finance, Economics and
Business, 6(4), 189-199. https://doi.org/10.13106/jafeb.2019. vol6.no4.189

Rubber Authority of Thailand (RAOT). (2017). Para Rubber Statistics and Database. Retrieved May 2, 2020, from http:// www.raot.co.th/ewt_dl_link.php?nid=6175\&filename=index.

Smith, V. H. (2001). Federal Crop \& Crop Revenue Insurance Programs: Group Risk Plan Contracts. Briefing No. 12. Retrieved August 23, 2020, from https://www.ampc.montana. edu/documents/briefings/Breifing12.pdf.

Smith, V. H. (2003). Federal Crop and Crop Revenue Insurance Programs: Income Protection. Briefing No. 11 (Revised), October 2003. Bozeman, MT: Agricultural Marketing Policy Center, Montana State University. Retrieved August 23, 2020, from https://www.ampc.montana.edu/documents/briefings/ Breifing11.pdf.

Walters, C., \& Preston, R. (2013). Revenue Risk, Crop Insurance and Forward Contracting. In: 2013 AAEA: Crop Insurance and Farm Bill Symposium. October 8-9, 2013, Louisville, KY, Number 156821. Agricultural and Applied Economics Association. 